\title{
APOSPORY IN PTERIS SULCATA L.
}

\author{
W. N. SteIL \\ (WITH PLATES XVI, XVII, AND FOUR FIGURES)
}

\section{Historical}

Although apospory was discovered in the mosses by PRINGSHeIM (18) and Stahl (r9) a short time after apogamy had been found in Pteris cretica albo-lineata by FARLOW (II), apospory remained unknown in the Pteridophytes until Druery $(6,7)$ reported the phenomenon in Athyrium Filix-foemina var. clarissima Jones. Prothallia of this fern were observed to form either from the head or the stalk of the sporangium which was arrested in its development. The prothallia of aposporous origin produced antheridia and archegonia. DRUERY (8) also reported the first case of apical apospory, namely in Polystichum angulare var. pulcherrimum Wills. The tips of the leaves of this species of fern produced the gametophyte as a direct vegetative outgrowth.

Bower (2) published a brief summary of his investigations of apospory in Athyrium Filix-foemina var. clarissima Jones and Polystichum angulare var. pulcherrimum Wills, the material for the investigation having been placed at his disposal by DrUERY. Sex organs were also observed to develop on the prothallia of the Polystichum angulare variety. The main portion of the paper, however, is not concerned with original studies, but with a discussion of "short cuts" in the life history of the fern.

Apospory was also discovered by Bower (3) in Trichomanes pyxidiferum and $T$. alatum. In the former the gametophyte generation was produced from aborted sporangia; in the latter there was soral and apical apospory. Sex organs were formed in $T$. pyxidiferum, but in $T$. alatum archegonia were absent and antheridia were never developed to maturity. Only in T. alatum were sporophytes observed to develop from the aposporously produced prothallia, and these sporophytes were of apogamous origin. Bower did not seem to be convinced that apospory and 
apogamy in these cases were not induced by cultural conditions. He believes that if apospory might be expected to occur anywhere in the plant kingdom, it is in the Hymenophyllaceae, the gametophyte and sporophyte of which are more nearly alike in some respects than in any other homosporous ferns. Bower (4) later attempted to induce apospory in more than 46 species and varieties of ferns by placing the fronds with immature sporangia on moist sphagnum. In not a single instance, however, were gametophytic outgrowths obtained. In regard to the difficulty with which apospory is induced, he makes the following statement: "There is a marked disability on the part of ferns to bridge over the limits of the two generations by other means than by the formation of spores; the phenomenon is by no means a promiscuous one occurring readily and often, but a rare process, which seems to appear spontaneously under conditions not yet understood and is not readily induced."

FARLOW (12) found apospory in Pteris aquilina L. Prothallial growths were produced from sporangia which had aborted in their development. No advanced stages in the development of the prothallia were observed.

The first case of apospory from the young sporophyte of a fern was discovered by Druery (9) in a Lastrea variety (probably Lastrea pseudomas var. cristata). Later DRUERY (ro) also induced gametophytes aposporously by placing on moist soil portions of the leaves of Scolopendrium vulgare var. crispum Drummondae. The prothallia of this species developed both sex organs. Apical apospory was reported by DRUERY in Athyrium Filix-foemina var. clarissima Bolton. He grew sporophytes from the aposporously produced prothallia of Lastrea pseudo-mas var. cristata. These were of apogamic origin and of interest since they possessed characters of both sporophyte and gametophyte.

STANSFIELd (20) brought into contact with the soil portions of the fronds of Athyrium Filix-foemina var. uncoglomeratum and thus induced gametophytes aposporously. When "pinnulets" and "leaflets" of young sporophytes, produced by the prothallia of aposporous origin, were pinned down to the soil, he again obtained readily the gametophyte generation. From the young sporophytes 
of 4 forms of Polystichum angulare, one of Lastrea, and 3 of Athyrium Filix-foemina, StANSFIELd in a similar manner induced apospory. $\mathrm{He}$ is inclined to believe that apospory may be induced by the same method in many other species of ferns.

Goebel (14) discovered apospory in Asplenium dimorphum. The ends of a finely divided leaf of a plant of this species produced prothallia, typically heart-shaped, and bearing both archegonia and antheridia. The nuclear history was not investigated, but GOEBEL suggests that reduction theoretically occurs when the prothallia are formed. GOEBEL (I5) successfully induced apospory in Aneimia Dregeana, Alsophila van Geertii, Ceratopteris thalictroides, Gymnogramme chrysophylla, Polypodium aureum, and Pteris longifolia. In Marsilia Drummondii and two Adiantum species the results were negative. The primary leaves of young sporophytes were removed and placed on sterilized loam and peat. From the lamina and petiole of the leaf, thus treated, there were produced gametophytes, sporophytes, or forms intermediate in character, since such outgrowths in some cases bore both antheridia and stomata. The aposporously produced prothallia of Pteris longijolia developed antheridia and archegonia. Sporophytes were not, however, observed to develop from the prothallia. Since there was found no great difference between the nuclei of the two generations, GOEBEL concludes that there is no sharp line of demarcation between gametophyte and sporophyte. As a result of a series of experiments, GoEBEL found that young sporophyte tissue possesses greater power of regeneration than old tissue. Contrary to BOWER's view that apospory is induced with difficulty and is rare, GOEBEL is convinced that the phenomenon can be produced readily and is widely distributed in ferns. Considered from the phylogenetic point of view, GoEBEL regards the prothallium of the fern as a rudimentary leaf, bearing sexual organs.

In a preliminary note on the cytology of apospory, Miss DigBy (5) described her results in inducing apospory in Lastrea pseudo-mas var. cristata, the aposporal nature of which first had been reported by DRUERY (9). As a result of the study of the nuclear condition of the fern, it was reported that 50 chromosomes were retained throughout the life cycle. 
FARMER and Digby (I3) published some very interesting results of their cytological studies of apospory and apogamy in ferns. Five of the 7 species which they investigated produced gametophytes aposporously. The aposporous nature of the 4 following was observed first by DrUERY: Athyrium Filix-foemina var. clarissima Jones, A. Filix-foemina var. clarissima Bolton, Scolopendrium vulgare var. crispum Drummondae, and Lastrea pseudomas var. cristata apospora. The fifth, Athyrium Filix-foemina var. uncoglomeratum, was first observed as an aposporous form by STANSFIELD (20). The origin of the aposporously produced prothallia in the different ferns was studied with special reference to changes in the chromosome number, and it was discovered that either the haploid or the diploid number is retained throughout the life cycle. In Athyrium Filix-foemina var. clarissima Jones; the embryo formed by the prothallia of aposporous origin is apogamic. Ninety chromosomes, the diploid number, are found in both generations. The embryo of Lastrea pseudo-mas var. cristata apospora is also of apogamic origin, but the chromosome number, between 60 and 78 , is probably the reduced number. The other 3 species were found to be parthenogenetic. In Athyrium Filix-foemina var. clarissima Bolton, 84 chromosomes were counted, in A. Filix-foemina var. uncoglomeratum about 100, and in Scolopendrium vulgare var. crispum Drummondae 70 chromosomes were found in the gametophyte, and between 80 and roo in the embryo sporophyte. Since 64 chromosomes were present in the sporophyte of this species, FARMER and Digby were inclined to believe that the diploid number of chromosomes are present.

Woronin $(\mathbf{1 2}, 24)$ studied apogamy and apospory in the following species of ferns: Trichomanes Kraussii, Pellaea flavens, P. nivea, $P$. tenera, Notholaena Eckloniana, and $N$. sinuata. In Trichomanes Kraussii sporangia were not produced, but prothallia were formed in large numbers from portions of leaves which were brought into contact with the soil. According to WoronIN, antheridia were in some instances produced directly from the leaves of the sporophyte. It appears, however, that there is not an omission of all the prothallial portion, but that there is formed in each case a short filament which may not be considered as the stalk of an antheridium. 
Apospory was induced in Pellaea flavens by growing prothallia in continued darkness. When prothallia were transferred to sand cultures there were produced some aposporous growths, but the tendency to apospory was not pronounced. The aposporously produced prothallia in both species in turn produced apogamous embryos and antheridia. Aposporous prothallia were also induced as a result of regeneration experiments. When a portion of the sinus of the prothallium with a young embryo was removed and maintained in culture, aposporous prothallia were occasionally formed. When primary leaves were cut off and similarly placed under cultural conditions, prothallia were produced which developed antheridia but no apogamous embryos.

\section{Materials and methods}

A large number of cultures of Pteris sulcata L. were made during the past 3 years by sowing the spores on sterilized sphagnum saturated with a one-tenth of I per cent Knop's solution or Beyerinck's solution as modified by MoORE (I7). The spores for the cultural work were obtained from Dr. A. B. Stout, Bronx Botanical Garden, New York, and Dr. E. B. Copeland, Los Baños, Philippine Islands. An abundant supply of spores was also obtained from a plant grown in the university greenhouse.

In one of the cultures made March I, I9r6, the aposporous developments to be described in this paper appeared. Many young apogamously produced sporophytes were found in the culture and on January I, I9I7, some of the young embryos presented a somewhat unusual appearance. As a result of microscopical examination it was discovered that prothalloid portions were present in certain parts of the sporophytes. In June I9I 7 a number of aposporously developed prothallia were found to be present. When some of the prothallia produced by the germination of the spores were transferred to a new culture, made in a similar manner to that of the original one, more aposporous developments were produced.

The prothallia and embryos from which the drawings and photographs were made were fixed in chrom-acetic acid solution diluted with 5 parts of water, stained with Haidenhain's iron haematoxylin, 
and mounted in glycerine jelly. Some of the drawings were made from living material. The sporophyte tissue is represented in the drawings by the darker shading; the gametophyte by the lighter shading.

\section{Observations}

The gametophyte of Pteris sulcata produced by the germination of a spore is in many respects similar to that of Pteris cretica var. albo-lineata described by FARLOW (II) and DEBARY (I). When the prothallia of both species were grown under the same cultural conditions, it was observed that those of the former were somewhat larger. Archegonia were never found on any of the large number of prothallia carefully examined with the microscope. Antheridia occur commonly and frequently in great abundance. The antherozoids are apparently normal in every respect.

The embryo of Pteris sulcata is always produced apogamously. Such a development of the embryo was first described by the writer (2I). Suminski (22) and later MERCKLIN (I6) observed tracheids in the prothallia of this species just posterior to the apical notch. DeBARY grew the prothallia of the same species, but observed no sporophytic cissue elements or any other indications of a sporophyte of apogamous origin. Accordingly he reported the fern as non-apogamous. The writer, however, has found the fern to be constantly apogamous under normal cultural conditions. From the sporophytes apogamously produced the gametophytic developments herein described appeared.

In every instance in my culture the prothallial portions or prothallia were produced in connection with the lamina or the petiole of the primary leaf. Usually the terminal portion of the leaf was in part or wholly prothalloid. Occasionally forms were observed which were intermediate in character, the cells partaking of the nature of both sporophyte and gametophyte. Sometimes

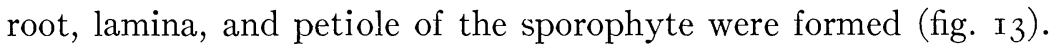
In some instances the root was absent (figs. 6, 8), and in still other cases only a well developed petiole was present (fig. 8), the lamina of the ordinary leaf being displaced by a prothalloid portion. The vascular system in the primary leaf as a rule was well developed. 
Prothallia were found, in one instance, growing from both surfaces of the leaf (fig. 5). These closely resembled the prothallia grown from the spore. The largest one of these was ribbon-like, but the others were mere filaments, each consisting of a single row of cells. On the former an antheridium (a) was produced. Rhizoids had been formed from the same prothallium. Two antheridia $\left(a, a^{\prime}\right)$ had also been developed by a filament produced from the other side of the leaf. From one of these the antherozoids were discharged when the living prothallia, still attached to the lamina of the leaf, were examined under the microscope. The antherozoids were normal in appearance and actively motile. The prothallial growths were surrounded at their points of origin by normal sporophyte cells.

The gametophytic portions, present on the lamina of the primary leaf, may be large, as represented by figs. 6 and 7 , in each case of which the terminal portion is distinctly prothalloid. In addition to the large gametophytic portions, a number of smaller regions of the same nature were present on the lamina of the sporophyte represented by fig. $7(c, d, e, f)$ and a single one by fig. 6, $b$. These were almost wholly surrounded by sporophytic cells. A highly magnified view of $b$ is represented by fig. 9. There is, as the figure shows, a sharp line of demarcation between the cells of the two generations. The cells of the gametophytic portion slightly project above the surrounding sporophyte cells. The smaller areas (fig. $7, e, f)$ were partially surrounded by cells of a somewhat intermediate character $(n)$. The chloroplasts in these cells were less numerous and smaller than those in the neighboring gametophyte cells (fig. Io). Even in the living condition this area was almost colorless as compared with the dark green gametophytic areas, and could be readily distinguished with a hand lens. A cell of the same character as those in the paler region just described was found, in one instance, in the larger gametophytic portion represented by fig. 7. This cell was wholly surrounded by ordinary gametophyte cells (fig. I). From the lower part of the petiole, represented by fig. 6, a prothallial portion $(p)$ had been formed. A leaflike and sporophytic growth $(s)$ had also been produced in this case. Three projections 
$\left(m, m^{\prime}, m^{\prime \prime}\right)$, of the nature of secondary prothallia, had also been produced from the terminal gametophytic portion.

The lamina of the leaf in some cases was wholly absent, the petiole being, however, well developed and resembling that of an ordinary leaf (fig. I6). From the ventral

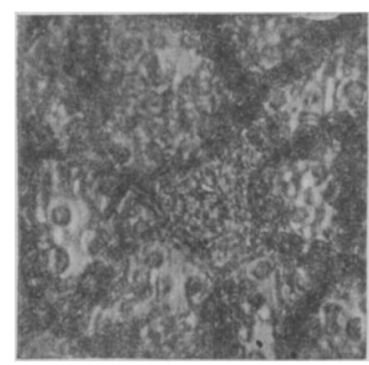

Fig. I.-Cell of somewhat intermediate character surrounded by ordinary gametophyte cells; $\times 2$ Iо surface of each of the two large terminal gametophytic portions $(b, c)$ numerous antheridia $(a)$ had been formed. From the dorsal surface of one of the prothallial portions (b) two small secondary prothallia $\left(m, m^{\prime}\right)$ had begun their development. The vascular system, which was generally well developed in this portion of the embryo sporophyte, extended for some distance into the terminal gametophytic portion. Between the gametophytic and sporophytic portions the cells were of an intermediate character, as shown in fig. 2, which is a highly magnified portion taken at $t$. From the petiole of the same sporophyte a prothallial portion $(p)$ had been produced. This outgrowth bears no relation to the vascular system of the petiole. The much modified primary leaf just described was developed in connection with a root and normal secondary leaves.

A structure similar to the preceding one is represented by fig. 8 . The petiole appeared to be well developed but both lamina and root were absent. The terminal portion was also distinctly gametophytic in nature and on both

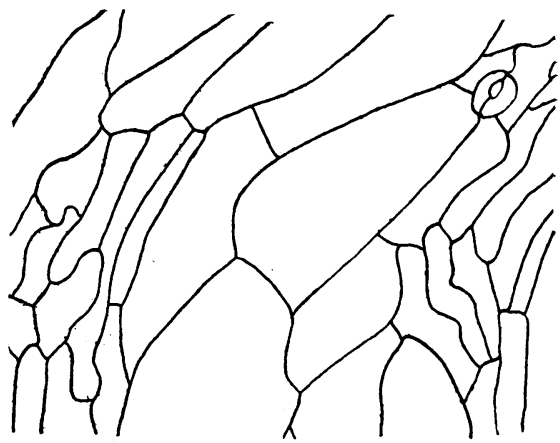

Fig. 2.-Peculiar cells, intermediate in character, of Pteris sulcata; $\times \mathrm{r} 62$. surfaces numerous antheridia

(a) of different sizes and secondary prothallia had been produced.

An interesting form is represented by fig. I3, since the single large gametophytic portion has been produced in connection with 
both petiole and lamina of the leaf. The development of the gametophytic portion was observed for several months and during this period grew rapidly. In the meantime the first secondary leaf had been produced. From both surfaces of the prothallium projections appeared, one of which resembled a young sporophyte $(s)$. In this case a root $(r)$ had been produced. The two projections $(o)$ on the same surface of the prothallium (fig. I 5) were similar to those appearing on the other surface, which with a small portion of the prothallium are shown highly magnified in fig. I4. While there is no marked difference between the form of the cells of the outgrowth and the prothallium, those of the latter are much larger. Whether any or all such projections produce embryos was not determined. If the aposporously produced prothallia of Pteris sulcata are like those developed from the germination of a

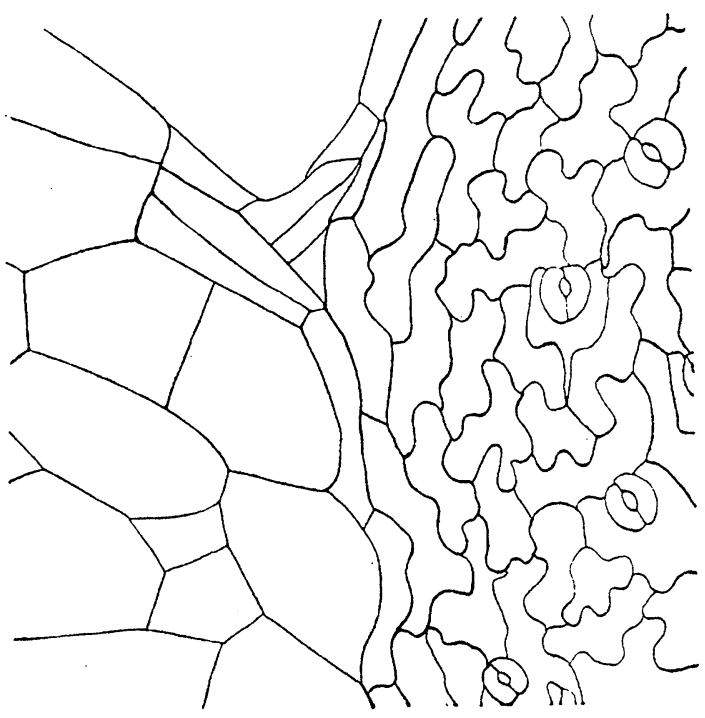

FIG. 3.-Cells of Pteris sulcata between gametophyte and sporophyte; $\times$ I 70 . spore, and I am inclined to think that they are, such growths may produce prothallia, cylindrical in form, sporophytes normal in every respect, or forms intermediate in character between gametophyte and sporophyte. These were frequently observed to develop from the prothallia in the culture. On the surface of the prothallium, from which the single projection appeared, a number of antheridia had also been formed. The nature of the cells of the two generations is shown in a highly magnified portion of the region between the lamina of the leaf and the prothalloid part $(d)$. There is also in this case a sharp line of demarcation between the two generations (fig. 3). 
A number of forms were found in the culture which were intermediate in character, as shown by fig. II. This growth resembled the leaf of an ordinary sporophyte. Typical epidermal cells including stomata, always present on the lamina of a leaf, were absent in this instance. No structure resembling a root was present. Fig. 4 shows the terminal portion of the lamina-like part.

An effort was made to study the nature of the development of the prothalloid portions from the earliest stages. The earliest

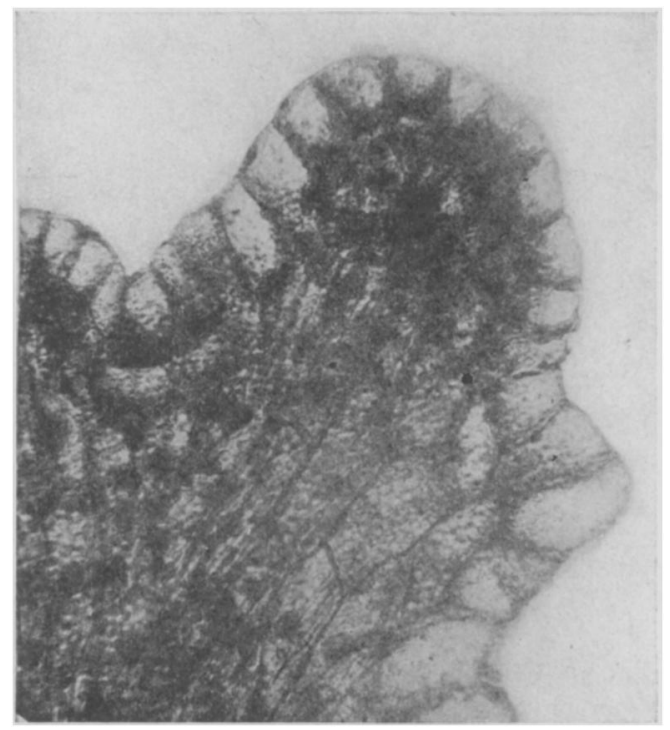

Fig. 4.-Terminal portion of leaflike structure of Pteris sulcata; $\times_{322}$. stage found was one composed of 4 or 5 cells, formed in connection with the petiole of the primary leaf. For several days the growth was followed and during that time a number of cells had been produced, as shown in fig. I2. When the earliest stages were observed the leaf had already emerged from the prothallium, and distinctly gametophytic cells could then be seen. Since the number of instances of apospory appearing in the culture was not large, as compared with the number of sporophytes, a favorable opportunity to study the stages in sections was not offered. It is certain that such forms represented by figs. 8 and 16 were never wholly sporophytic and later became gametophytic. From such an instance as shown in fig. 5, however, it could readily be conceived that the prothallia developed from the primary leaf which was distinctly sporophytic in character. 
It seems not improbable that the gametophytic cells were present at the earliest stages in the development of the embryo. Since the sporophyte of Pteris sulcata is of apogamous origin, there is an intimate connection between the cells of the gametophyte and the sporophyte. These cells may be carried upward by the sporophyte, and, retaining their power to divide, they may give rise to the gametophytic portions which have been described.

It has not so far been possible to state the conditions under which apospory occurred in the culture of the prothallia of Pteris sulcata. All attempts to induce the phenomenon have failed. Young sporophytes grown in subdued light produced no gametophytes aposporously. Portions of the leaves of young and old sporophytes when placed on moistened sphagnum also failed to develop prothallia.

The nuclear history of Pteris sulcata was not followed. It is very probable, from studies so far made, that there is no change in the chromosome number when the apogamous embryo originates. It is also likely that when the gametophyte is formed in connection with the embryo sporophyte there is no change in the chromosome number. On account of the limited number of aposporous developments in the culture no favorable opportunity was presented to count the chromosomes at a point in the life history when the gametophyte originates. It is believed, however, that the gametophyte thus produced and one formed by the germination of the spore have the same number of chromosomes.

The changes which are involved in the formation of an embryo of apogamous origin, except in the two Lastrea pseudo-mas varieties described by FARMER and DigBY, are unknown. In these ferns, according to their description, fusion of adjacent prothallial cells and their nuclei initiate the formation of the embryo with the diploid number of chromosomes. It is certain from studies already made that such changes are not involved in any of the apogamous species which I have had an opportunity so far to investigate. Until the exact nature of the changes which are involved when the apogamous embryo originates are known, however, the origin of the aposporous developments in Pteris sulcata cannot be explained in a satisfactory manner. 


\section{Summary}

I. The gametophyte generation of Pteris sulcata L. is ordinarily produced by the germination of a spore.

2. The embryo sporophyte is of apogamous origin.

3. The gametophyte generation of Pteris sulcata under certain conditions was produced aposporously.

4. The gametophytic portions or gametophytes were formed in connection with the lamina or the petiole of the primary leaf. In one instance a prothallium was produced from both lamina and petiole of the primary leaf. A sharp line of demarcation usually exists between the cells of the gametophyte and the sporophyte.

5. The prothallial portions developed antheridia, secondary prothallia, and in one instance a sporophyte-like outgrowth.

6. The antherozoids, produced by the aposporously developed prothallia, were actively motile and normal in appearance.

7. Occasionally forms intermediate in character between gametophyte and sporophyte were formed.

8. It seems probable that the origin of the aposporously produced gametophyte may be traced to an early stage in the development of the embryo. Since the embryo, on account of its apogamous origin, is intimately connected with the prothallium, it is not impossible that in some way cells of the prothallium may be embodied in the developing embryo. These cells, retaining the power to divide, may produce such outgrowths as have been described.

\section{LITERATURE CITED}

I. BARY, A. DE, Über Apogamie Farne und die Erscheinung der Apogamie im Allgemeinen. Bot. Zeit. 36:449-487. pl. 14. I878.

2. BOWER, F. O., On apospory in ferns. Jour. Linn. Soc. $21: 360-368$. pls. IO, II, figs. 5. I 884 .

3. - On some normal and abnormal developments of the oophyte of Trichomanes. Ann. Botany $\mathrm{x}: 269-305$. pls. 14-16. 1888 .

4. - - Attempts to induce aposporous developments in ferns. Ann. Botany 4: I68-I69. I889.

5. Digby, L., On the cytology of apogamy and apospory. II: Preliminary note on apospory. Proc. Roy. Soc. 463-468. figs. 3. I905.

6. Druery, C. T., Observations on a singular development in the lady-fern. Jour. Linn. Soc. 2 r:354-360. 1884. 
7. Druery, T. C., Further notes on a singular mode of reproduction in Athyrium Filix-foemina var. clarissima. Jour. Linn. Soc. 21:358-36o. figs. 2. 1884 .

8. - On a new instance of apospory in Polystichum angulare var. pulcherrimum Wills. Jour. Linn. Soc. 22:437-44I. fig. I. I886.

9. - Notes upon an aposporous Lastrea (Nephrodium). Jour. Linn. Soc. 29:479-483. pl. 34. I892.

ro. - Notes upon apospory in a form of Scolopendrium vulgare var. crispum and a new aposporous Athyrium, also an additional phase of aposporous development in Lastrea pseudo-mas var. cristata. Jour. Linn. Soc. $30: 28 \mathrm{I}-284$. pl. 17 . 1893 .

II. FARLOW, W. G., An asexual growth from the prothallus of Pteris cretica. Quar. Jour. Micr. Sci. 14:226-273. pls. IO, II. I874.

12. - Apospory in Pteris aquilina. Ann. Botany 2:383-386. 1889.

I3. FARmer, J. B., and DigBy, L., Studies in apogamy and apospory in ferns. Ann. Botany 2r: r6r-r99. pls. r6-20. I907.

14. GoebeL, K., Kleiner Mitteilungen 3. Aposporie bei Asplenium dimorphum. Flora 95:239-244. I905.

15. - Experimentell-morphologische Mitteilungen. I. Künstlich hervorgerufeue Aposporie bei Farnen. Sitz. Königl. Bayer. Akad. Wiss. 37: II9-I37. I907.

16. Mercklin, C. E., Beobachtungen an Prothallium der Farnkräuter. St. Petersburg. I850.

I7. Moore, G. T., Methods for growing pure cultures of algae. Jour. Appl. Microscopy 6:2309-23I4. I903.

18. PringsheIm, N., Vegetative Sprossung der Moosfrüchte. Monatsbericht der königlichen Akademie der Wissenschaften zu Berlin. 425-429. I876.

19. Stahl, E., Über künstlich hervorgerufene Protonemabildung an dem Sporogonium der Laubmoose. Bot. Zeit. 34:689-695. I876.

20. Stansfield, F. W., On the production of apospory by environment in Athyrium Filix-foemina var. uncoglomeratum. Jour. Linn. Soc. 34:262268. I899.

2r. Steil, W. N., Studies in some new cases of apogamy in ferns. Bull. Torr. Bot. Club 45:93-108. pls. 4, 5. r9ı8.

22. Suminski-Leszczyc, Zur Entwickelungsgeschichte der Farnkräuter. Berlin. 1848 .

23. Woronin, H., Apogamie und Aposporie bei einigen Farnen. Ber. Deutsch Bot. Gesells. 25:85, 86. I907.

24. - Apogamie und Aposporie bei einigen Farnen. Flora 98: IoI-I62. 1908. 


\section{EXPLANATION OF PLATES XVI, XVII}

All of the drawings were made with the aid of a camera lucida. Figs. $5,6,7,8, \mathrm{II}, \mathrm{I} 3$, and $\mathrm{I} 6$ represent a magnification of about 30 times. All the other figures, with the exception of fig. Io, were drawn with a magnification of about 325. Fig. Io represents a slightly greater magnification. The drawings were reduced one-half in reproduction.

\section{PLATE XVI}

FIG. 5.-Lamina of primary leaf of sporophyte of Pteris sulcata from both surfaces of which a number of prothallia appear as outgrowths of leaf blade; $a, a^{\prime}$, antheridia.

Fig. 6.-Sporophyte of Pteris sulcata with large terminal prothallial portion formed in connection with primary leaf; $m, m^{\prime}$, and $m^{\prime \prime}$, young secondary prothallia; $b$ and $p$, prothallial portions; $s$, leaflike outgrowth.

FIG. 7.-Another sporophyte with large terminal prothallial portion; $c, d, e$, and $f$ smaller prothallial portions; $n$, "light" area, cells being neither characteristically sporophyte nor gametophyte.

FIG. 8.-Sporophyte with well developed petiole of primary leaf; lamina displaced by prothalloid portion; $p$, old prothallium; $a$, antheridium.

FIG. 9.-Highly magnified portion of gametophytic region $(-b)$ and neighboring sporophyte cells shown in fig. 2 .

Fig. Io.- Highly magnified portion of $n$ and neighboring cells shown in fig. 3 ; chloroplasts are less numerous and smaller in paler region than in prothallial cells; cells of paler region are somewhat intermediate in form, partaking of nature of both generations.

FIG. I I.-Leaflike portion; epidermal cells of lamina not typically sporophyte, being regular in form and lacking stomata.

FIG. I 2.- Early stage in development of prothallium $(p)$ in connection with petiole of primary leaf.

\section{PLATE XVII}

FIG. I3.- Sporophyte with prothallium produced from both lamina and petiole of primary leaf; $o$, outgrowth from one surface of prothallium.

FIG. I4.- Highly magnified view of outgrowth (o) shown in fig. 9; cells in outgrowth much smaller than those of prothallium.

FIG. I5.-Three outgrowths ( $o$ and $s$ ) on other surface of prothallium represented in fig. $9 ; r$, rootlike portion of outgrowth $(s)$.

Fig. I6.-Primary leaf of sporophyte; $b$ and $c$, prothallial portions; $m$, $m^{\prime}$, secondary prothallia developed from dorsal surface of $b ; p$, prothallium developed from petiole; $a$, antheridium. 


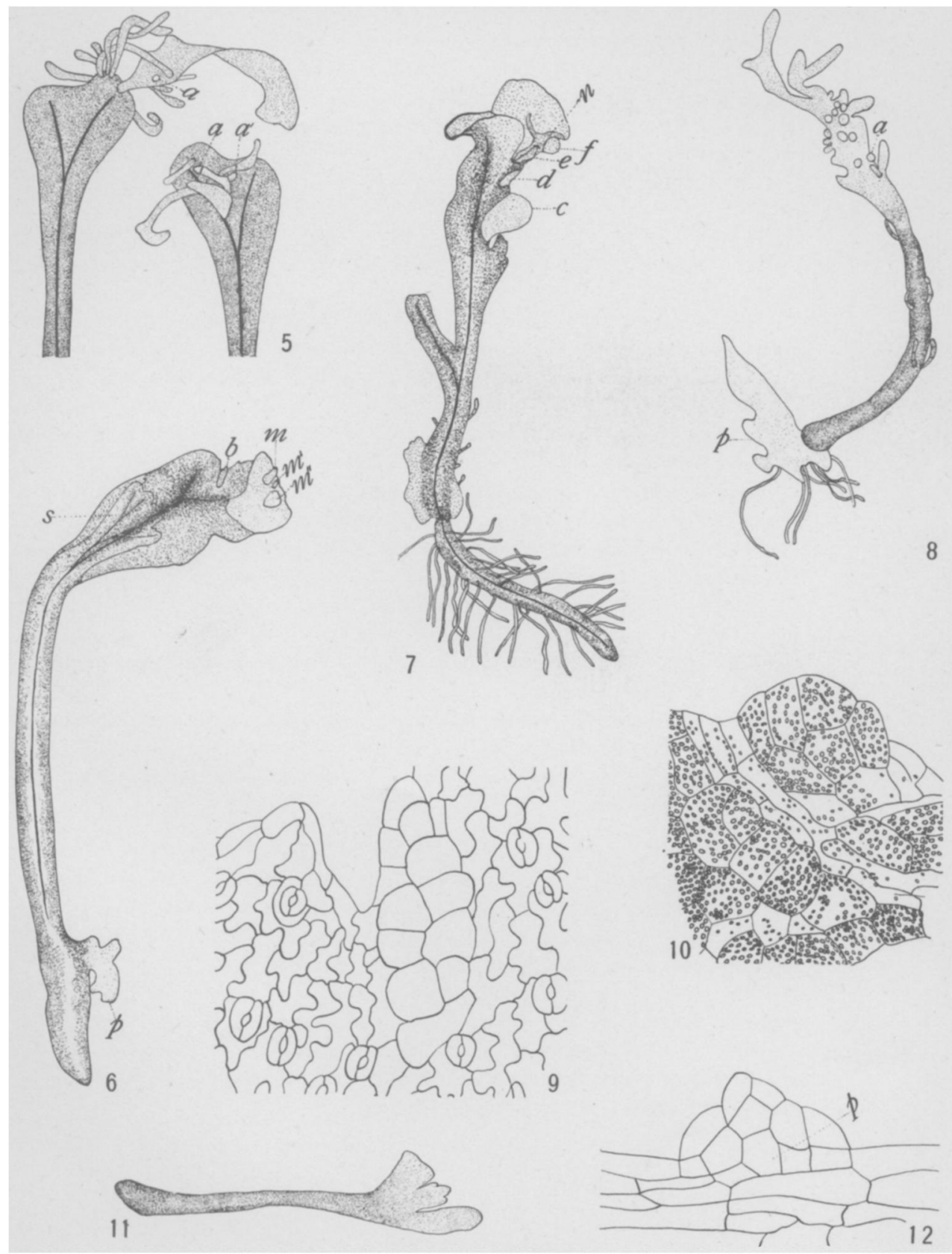

STEIL on PTERIS

This content downloaded from 080.082.077.083 on February 19, 2018 19:14:45 PM All use subject to University of Chicago Press Terms and Conditions (http://www.journals.uchicago.edu/t-and-c). 


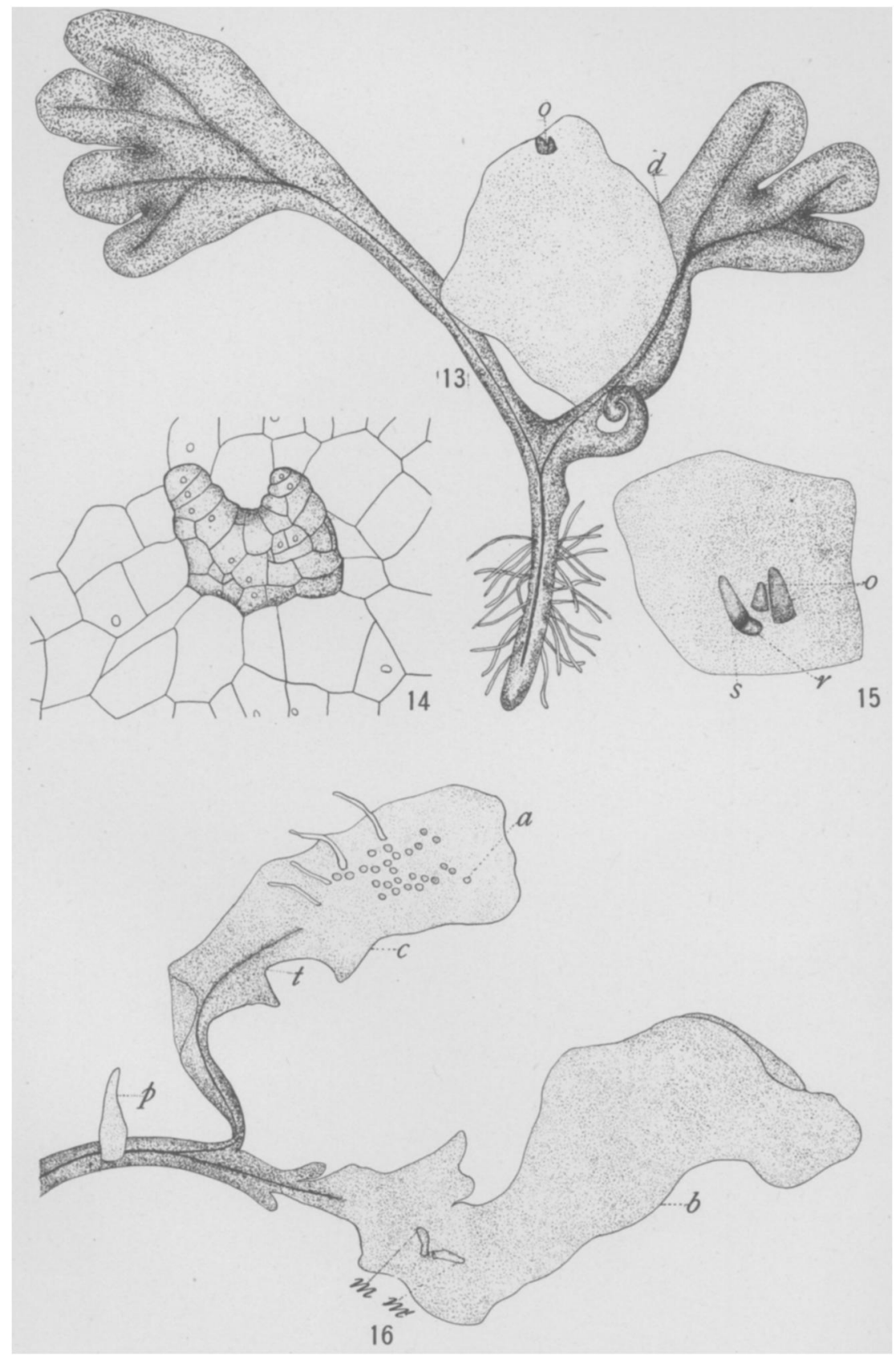

STEIL on PTERIS

This content downloaded from 080.082.077.083 on February 19, 2018 19:14:45 PM All use subject to University of Chicago Press Terms and Conditions (http://www.journals.uchicago.edu/t-and-c). 